Vol. 7, No. 2, 2020

https://doi.org/10.23939/eem2020.02.112

UDC 339.138:168.522

Jel Classification Code B41, M31

P. Chlipala

Cracow University of Economics, Poland, Professor UEK, Dr. hab.

E-mail: pawel.chlipala@uek.krakow.pl

ORCID: 0000-0003-2496-8617

\title{
METHODOLOGY OF MARKETING VS METHODOLOGY OF SOCIAL AND ECONOMIC RESEARCH
}

\begin{abstract}
The presented paper is methodical in character. Marketing methodology is an important matter looking from the prism of identifying its scientific status. There are differing views on the scientific status of marketing, nevertheless marketing, from the perspective of scientific cognition, has developed dynamically throughout its entire history. The main objective of this article is to present the methodological dilemmas of marketing in the context of social and economic sciences. The foundations of the methodology of research on marketing cannot be separated from the methodology of social sciences. Marketing belongs to social sciences, so it is based on similar assumptions with regard to the character of reality and scientific cognition. Marketing is engaged in exploring human behaviour and, similarly to other social sciences, makes use of such research methods and techniques. It is difficult to conduct research in the area of marketing without referring to the methodology of social sciences.The article presents the foundations of marketing research methodology, assumptions of the analysis of methodology of research on marketing in comparison to methodology of social and economic research and final remarks.
\end{abstract}

Key words: marketing, marketing research, social research, economic research, marketing methodology, economic research methodology, social research methodology.

\section{Introduction}

The methodology of marketing research is a significant issue from the perspective of an attempt to identify the scientific status of this discipline of knowledge. Marketing has a history of more than one hundred years as an area of scientific research and an academic discipline (Sagan, 2005, p. 2;
Kamiński 2010, p.6; Kamiński 2012, p. 2). In terms of the time of its activity, it is not inferior to sociology or scientific management. Marketing, from the perspective of scientific cognition, has developed dynamically throughout its entire history. From the point of view of contemporary times, the second decade of the $21^{\text {st }}$ century, attention should be given to its identity which mainly comprises marketing's scientific status and academic position. The identity and scientific character of marketing have been the subject of much controversy since the 1950s, and in Poland with much intensity - since the beginning of the $21^{\text {st }}$ century. The first attempts to identify the scientific foundations of marketing were made by R. Bartels (Sagan, 2005, p. 2; Shaw \& Tamilia, 2001).

Several dozen years of disputes over the scientific status of marketing have not led to any agreement. The extreme opinions on this issue can be divided into three groups. K. Hutchinson and his followers claim that marketing will never be a science, while other scientists, e.g. Sh. Hunt, believe that marketing has achieved the status of a science (Szumilak, 2005, p. 2). In Poland, a widely known opinion was expressed by J. Dietel, who notes that marketing is a practical area, indispensable to company operations, it has an increasingly important role in business activities, but is also employed on a large scale in non-profit organizations. Marketing's problem in this context is the fact that it does not possess its own theory, methods and methodology, so it cannot aspire to 


\section{Methodology of marketing vs methodology of social and economic research}

become a science (Dietl, 2001; Dietl, 2000). L. Żabiński expressed the opposite opinion arguing that marketing has its own paradigms, original terminology, research categories, and even unique research procedures which allow for creating its own framework (Żabiński, 2002). Kamiński (2016), having analysed marketing literatures, concluded that the science of marketing is distinguished by its original area of interests. The third group of scientists argue that marketing does not actually meet the criteria of a science, which does not exclude such a possibility in the future. Sz. Figiel noted that due to its interdisciplinary character and complexity, as well as the fragmentation of knowledge and lack of methodological autonomy, marketing cannot be treated as science. Simultaneously, a greater focus of research areas and methodological regime would enable marketing to develop a theory for predicting market phenomena (Figiel, 2004).

A review of the methodology of social and economic sciences leads to the conclusion that marketing, in its search for identity, is in a similar situation. The presented paper is methodical in character. Its objective is to present the methodological dilemmas of marketing in the context of social and economic sciences (Chlipała, 2018, pp. 38-49, 88-98).

\section{Marketing - the foundations of research methodology}

The defining of the foundations of the methodology of research on marketing should start with distinguishing between two terms: research on marketing and marketing research. Research on marketing refers to the process of gathering knowledge about marketing aimed to create a marketing theory. Research on marketing adopts a scientific perspective - it is cognitive in character and a macroeconomic dimension (Pilarczyk \& Wanat, 2009). Marketing research is usually viewed from a microeconomic perspective, i.e. the perspective of the marketing problems of individual businesses, and is conducted for commercial purposes. It refers to a process of gathering market information - competitors and customers, as well as information about a company's environment and the effects of its marketing activities for the purpose of making effective and efficient marketing decisions (Sagan, 2004, p. 9-10; Kędzior \& Karcz, 2001, p. 20).

Due to the dominance of practical dimensions over a scientific domain in contemporary marketing, research on marketing is frequently identified with marketing research (Kaczmarczyk, 2003 , p. 15). It also results from the fact that research on marketing and marketing research are not different in terms of procedures, data gathering methods and analyses of research results. However, the two areas differ from the perspective of their objectives and the manner in which they use and disseminate knowledge. It seems that these differences justify treating the two areas separately.

Research on marketing can have a historical character - presenting reflections on its evolution and development - or it can focus on exploring its current status and components. Research on marketing should serve to create paradigms and theoretical concepts, providing knowledge about marketing. Getting acquainted with marketing conditions the creation of its academic status, being an integral component of its identity as a scientific discipline. There are three basic methodological paths of seeking knowledge in marketing and about marketing: critical, positivist and interpretative (Sagan, 2013, p. 34). Critical methodology is engaged is social issues - researchers employing critical methodology intend not only to get to know reality, but they also try to shape it. In the context of a researcher's attempts to improve social life and environment, critical methodology is opposed to the two other approaches: positivism and interpretationism. In the above methodological paths, researchers focus exclusively on the cognitive sphere: they gather and disseminate results. In the positivist trend, which dominates marketing, they seek to create reliable and unquestionable knowledge which is independent of time. In the interpretative trend knowledge is deepened but local and dependent on culture, time and context.

Since the beginning of the $21^{\text {st }}$ century more attention has been given to historical and methodological studies in the critical trend, but marketing scientists still show very little interest in this issue (Shankar, 2009, p. 683, 690). According to A. Shankar, critical marketing is a marginal area 


\section{P. Chlipata}

of marketing thought as compared with the main trend (Table 1).

Table 1.

Systems of marketing thought

\begin{tabular}{|l|l|l|}
\hline Description & $\begin{array}{c}\text { Internal group } \\
\text { of recipients - } \\
\text { scientific } \\
\text { community }\end{array}$ & $\begin{array}{c}\text { External group of } \\
\text { recipients - non- } \\
\text { scientific } \\
\text { community }\end{array}$ \\
\hline $\begin{array}{l}\text { Instrumental } \\
\text { knowledge }\end{array}$ & $\begin{array}{l}\text { Main, academic } \\
\text { trend in } \\
\text { marketing }\end{array}$ & $\begin{array}{l}\text { Main, applicatory } \\
\text { trend in marketing }\end{array}$ \\
\hline $\begin{array}{l}\text { Reflective } \\
\text { knowledge }\end{array}$ & $\begin{array}{l}\text { Critical } \\
\text { marketing }\end{array}$ & $\begin{array}{l}\text { Intelligent } \\
\text { marketing }\end{array}$ \\
\hline
\end{tabular}

Source (Shankar, 2009, p. 683)

The typology of systems of marketing thought, proposed by A. Shankar, was based on two variables: a group for which knowledge is created, and the character of knowledge. A distinction was made, following an earlier work of M. Burawoy, between instrumental knowledge fairly narrow, specialised, but created with attention to procedures and reliability (Burawoy, 2004), and reflective knowledge - much more general, comprehensive and broad. Academic marketing in the main trend and critical marketing are shaped by the community of scientists engaged in this discipline. A. Shankar pointed to another group of recipients - students and the representatives of business practice. With regard to "intelligent marketing", attention should be given to the followers of the critical trend (e.g. philosophers), who express their opinions on marketing, and the representatives of other professions (e.g. journalists).

\section{Methodology of research on marketing vs methodology of social and economic research - assumptions of the analysis}

The foundations of the methodology of research on marketing cannot be separated from the methodology of social sciences. Marketing belongs to social sciences, so it is based on similar assumptions with regard to the character of reality and scientific cognition. Marketing is engaged in exploring human behaviour and, similarly to other social sciences, makes use of such research methods and techniques as observations, reviews, surveys, etc., but their usage has a different scope and frequency. It is difficult to conduct research in the area of marketing without referring to the methodology of social sciences.

Being aware that marketing is part of economic sciences, it is necessary to refer in this work to the methodology of this field. The important aspect is the common root of economic sciences - interest in economic entities.

Presented below are the methodological problems of marketing in the context of the main issues of social and economic sciences. These sciences are characterised by a different degree of generality. Social sciences represent the broadest concept. In the typology of sciences, they belong to real sciences and constitute (as humanities even in a broader context), apart from natural sciences, one of the main trends. Economic sciences are defined as part of social sciences, and management sciences belong to economic sciences. Because of different degrees of generality of the above disciplines, methodological issues are contained in each other.

It should be noted that in the presented considerations the methodology of scientific disciplines is linked to specific sciences. We deal here with the methodology of social research as well as with the methodology of sociological research, economic sciences and economics. Obviously, the methodology of economics can be discussed as part of the methodology of social sciences, while the presented disciplines have a major impact on creating the methodology of scientific disciplines, which implies that sociology had the greatest impact on the methodology of social sciences, while economics - on the methodology of economic sciences. The below characteristics of methodological problems are presented from two perspectives - a general one, referring to the discipline of sciences, and the specific perspective - the science that is most strongly correlated with the analysed discipline.

\section{Methodology of social and sociological research vs cognition in marketing}

The methodology of social research comprises a number of disciplines including economics, sociology, psychology, law, pedagogy, management, accounting, finance as well as marketing. 


\section{Methodology of marketing vs methodology of social and economic research}

Regardless of the level of advancement and scientific maturity, the above-mentioned disciplines make use of procedures, methods and techniques relevant to social sciences. Because of their specificity with regard to the researched areas and adopted assumptions they use such methods and techniques in varying degrees. For example, observation research is much more commonly used in sociology than in marketing. However, social research viewed in a broad perspective allows for outlining general problems characteristic of this type of research regardless of which specific discipline makes use of particular methods.

The methodology of social research represents a wide range of approaches and analytical and research methods which can be employed by scientists dealing with social sciences. Social research, unlike natural sciences research, is a discipline focused on exploring social realities. Its objective is to investigate social institutions, phenomena and relationships (Sztumski, 2010, pp. 12-22). The common characteristic of social sciences is their focus on exploring and explaining human behaviour. Each of specific sciences analyses a certain fragment of social reality. Research on marketing explores economic phenomena connected with the exchange of goods and services and related values, as well as relationships among economic entities and entities engaged in cooperation with consumers.

Social sciences employ various methodical approaches and orientations, relying on specific ontological, axiological and epistemological assumptions. A review of literatures on the scope of the methodology of social research leads to the final conclusions about the adoption of methodical approaches (Somekh \& Lewin, 2011; Flick 2011; Babbie 2004; Rószkiewicz et al., 2014). The dominant assumption of social sciences is a relative ordering of social structure, aimed to achieve the regulation and satisfaction of social needs. This assumption is consistent with a functionalist and interpretative approach.

Literatures on social sciences can be divided into two groups: the first one is dominated by a positivist approach. Such analyses are often referred to as quantitative, but it is a certain simplification. The other group of manuals and monographs, apart from a positivist orientation (functionalist), presents an interpretative approach. Reality and cognition in this orientation are somewhat subjective, humans are not limited by the environment, and knowledge created by scientists is idiographic in character. This type of research is referred to as qualitative. D. Silverman notes that researchers usually follow one of the two methodical concepts. The author describes antagonisms between two groups (Silverman, 2007). Many researchers are not inclined, or even prepared to shape social knowledge on the basis of more than one methodical approach.

Despite the fact that functionalism and interpretationism are dominant methodical concepts in social sciences, literatures also present opinions expressed by the advocates of radical change. Examples include the feminist movement and post-modernism. Z. Bauman, a well-known representative of post-modernism, stressed the significance in contemporary sociology of a researcher's engagement in change and shaping reality (Bauman, 2010, pp. 643-644).

Scientific research on marketing is dominated by a positivist approach, with just a few examples of an interpretative approach and a combination of both orientations. It results from marketing's area of activity - the functioning of marketing could hardly be possible without assumptions concerning social equilibrium, the satisfaction of consumer needs, the development of individuals and social groups, or transactions and exchange. The question arises whether marketing could accept other research orientations. There are a number of areas such as social marketing or consumerism, in which there is much room for change and social improvement to be undertaken by researchers. This approach is likely to be adopted in the future, considering marketing's growing interest in social issues. However, the combination of research and creative functions in social interactions is much less likely in light of the tradition and history of marketing.

It should be noted that at the level of sociology a crucial role is played by theory. It is reflected in the attempt to create theory as a result of the research process and the adoption of preliminary the oretical assumptions and verification of theories. Undoubtedly, it results from sociology's rich output. J. H. Turner presented 


\section{P. Chlipata}

seven basic sociological orientations, constituting a theoretical and methodical framework of sociological thought: functionalism, evolutionism, conflict theory, exchange, interactionism, structuralism, and critical theory (Turner, 2005). Embedding research in theory and focus on creating theory constitute the essence of science. In this context, sociological research is much more advanced and mature than research on marketing. Therefore, it is necessary to postulate greater concentration on creating theory in research on marketing. A large number of research studies in this field merely result in formulating conclusions, and researchers do not aspire to generate theories or create knowledge that could lead to building theoretical constructs.

A significant role in developing sociological research is played by anthropological tradition. There are far-fetched correlations between sociology and ethnographic and ethnological research as well as cultural anthropology, depending on the adopted methodological tradition. Sociology is part of broadly understood anthropology as a science of man (Mauss, 2010, pp. 311-315). Anthropological research focuses on the social structure sociology's main area of interest (Geertz, 2005, p. 14). In-depth analyses based on participant observation make a significant contribution to developing sociological concepts, constituting a rich empirical output - both in the past and presently (Chwieduk \& Pomieciński 2008). It should be noted that the inspiration of ethnographic and anthropological research has a cognitive value for many aspects of marketing. Attempts are made to use the concepts of these types of research in marketing, but attention given to this methodical orientation is not sufficient.

\section{The methodology of economic sciences and economics in the context of research on marketing}

Economic sciences are based on the concept of humans who act in a rational way and make careful choices in the area of economic processes. This is a general assumption resulting from the definition and nature of economics. Identifying economic sciences with economics is a common practice. It is economics that dominated the perception of economic sciences as a result of treating it as a "hard" social science because of a large-scale application of mathematical rigour, econometric methods and modelling, which led at the end of the $20^{\text {th }}$ century to its dominant position as a social science (Brzeziński et al., 2009, pp. 50-51). However, theoretical and methodical disputes relate to the very definition of economics as well as its concepts and trends. The following issues are being given increasing attention (Brzeziński et al., 2009; Wotyna, 2009; Koźmiński, 2009; Malawski, 1999, p. 15):

- the necessity to depart from the classical concept of rational man and to consider psychological, social and cultural aspects of decision-making processes, as it is done in behavioural economics,

- the interdisciplinary character of problems and blurring of economic lines, reflected in an impact on sociology, psychology and management, accompanied by the simultaneous benefits derived from these fields; this interdisciplinary character becomes visible in economic research on mainstream economics;

- extended range of research instruments (data mining, case studies, content analysis) through borrowings from other disciplines belonging to social sciences,

- shifting the centre of gravity of scientific activity towards empiricism.

Certainly, it is still possible to identify the major subject of economic research - the classically understood purposefulness and rational of economic behaviours, as well as the allocation of economic resources, a dominant approach to research and a research procedure which consists in the creation and verification of an economic model, or, according to the adopted epistemological orientation, its falsification (Wojciechowska, 2011). On the other hand, the above-mentioned issues lead to the blurring of lines between economic sciences and other disciplines of science (from the perspective of the general level of the methodology of scientific disciplines), and they heat up disputes over the scientific status of economics (assessing the situation from the level of specific science). Some other problems in this context include the low prognostic capabilities of economics and its thematic incoherence. 


\section{Methodology of marketing vs methodology of social and economic research}

Disputes conducted by economics scientists over leading paradigms, the reliability of knowledge and its prognostic capabilities, the coherence of theories, the originality of research areas and methods are reflected in research on marketing. It is difficult to compare the range of disputable areas, but the scope of problems and criticism of a scientific status are very similar. It clearly shows how difficult it is to follow the restrictive norms of science within economic sciences, and, simultaneously, how important it is to define the boundaries of a research field and ensure the correctness and reliability of acquired knowledge.

In economic sciences it is possible to identify several thematic perspectives related to the limitations of cognition and assumptions concerning science.

The first level of disputes refers to the issue of the methodological dualism of economic sciences (Hanaszko, 2014; Surma et al., 2010; Krysiak et al., 2010). We can identify a naturalistic approach, which is rooted in positivism and based on the rigorous requirements of a scientific approach, aimed to parametrize and quantify economic phenomena. In contrast to naturalism, the humanistic trend assumes the concept of social, free and irrational man. A more significant role in this approach is played by an axiological perspective and an idiographic model of knowledge. The other group of problems relates to the role of economics in social life. This role can be considered in two dimensions: a descriptive and normative one. The first orientation seeks to describe and explain economic life, while the other one aims to change and improve the economic system (Balicki, 2002, pp. 15-21).

The above-mentioned divisions reflect the objective and subjective character of scientific cognition - a naturalistic approach derived from positivism and interpretationism is part of the concepts of humanism. In turn, the division into descriptive and normative economics reflects the division into social regulation and radical change. The former methodical approach separates the cognitive process from the application of knowledge, while the latter approach combines the two areas of activity.

\section{Concluding remarks}

A comparison of the methodologies of research on marketing should be also referred to other disciplines of science, for example management sciences, which - due to the formal limitations - is not discussed in this paper. The presentation of methodological dilemmas shows that many issues related to the identification of research areas, the boundaries of disciplines and the scientific status are also discussed within social and economic disciplines. Moreover, the issues related to cognition and knowledge verification are not ultimately resolved due to the specificity of social sciences and difficulties in generating reliable and unquestionable knowledge. However, it should be noted that both sociology and economics resort to a wider range of methodological orientations and approaches, which indicates that marketing should become more open for various research orientations, particularly interpretationism and critical methodology.

\section{References}

1. Babbie, E. (2004). Badania społeczne $w$ praktyce. Warszawa: Wydawnictwo Naukowe PWN.

2. Bauman, Z. (2010). Refleksja końcowa. O pisaniu, o pisaniu socjologii. In N. K. Denzin \& Y. S. Lincoln (eds.) Metody badań jakościowych, Warszawa: Wydawnictwo Naukowe PWN.

3. Brzeziński, M. et al. (2009). Między imperializmem a kooperacja. Ekonomia a inne nauki społeczne na poczatku XXI wieku. In B. Fedor \& Z. Hockuba (eds.) Nauki ekonomiczne wobec wyzwań wspótczesności. Warszawa: Polskie Towarzystwo Ekonomiczne.

4. Burawoy, M. (2004). Public Sociologies: Contradictions, Dilemmas, and Possibilities. Social Forces, 82 (4), pp. 1603-1618.

5. Chlipata, $P$. (2018). Integracja podejść metodologicznych w badaniach marketingu, Kraków: Wydawnictwo Uniwersytetu Ekonomicznego w Krakowie.

6. Chwieduk, A. \& Pomieciński, A. (Eds.). (2008). Francuska antropologia kulturowa wobec problemów wspótczesnego świata, Warszawa: Wydawnictwo Naukowe PWN.

7. Dietl, J. (2001). Perspektywy marketingu zmierzch czy rozwój?. In A. Czubała \& J. Wiktor (eds.) Marketing u progu XXI wieku. Księga jubileuszowa dla uczczenia 70. urodzin Profesora Jerzego Altkorna (pp. 35-44). Kraków: Wydawnictwo AE w Krakowie. 


\section{P. Chlipała}

8. Dietl, J. (2000). Some Remarks on Marketing Perspectives. In J. Ďad'o \& J.W. Wiktor (eds.) Marketing and Globalization (pp. 63-67). CracowBanská Bystrica: Cracow University of Economics, Matej Bel University.

9. Figiel, Sz. (2004). Problem poznania naukowego $w$ marketing. In: E. Duliniec et al. (eds.) Ekspansja czy regres marketingu? (pp. 31-36). Warszawa: Polskie Wydawnictwo Ekonomiczne.

10. Flick, U. (2011). Introducing Research Methodology. A Beginner's Guide to Doing Research Project, Los Angeles: Sage Publications.

11. Geertz, C. (2005). Wiedza lokalna. Dalsze eseje z zakresu antropologii interpretatywnej. Kraków: Wydawnictwo Uniwersytetu Jagiellońskiego.

12. Hanaszko, K. (2014). Dualizm metodologiczny nauk ekonomicznych (pp. 205-234). In: K. Kuciński (ed.) Naukowe badania zjawisk gospodarczych. Perspektywa metodologiczna. Warszawa: Wolters Kluwer.

13. Kaczmarczyk, S. (2003). Badania marketingowe. Metody i techniki. Warszawa: Polskie Wydawnictwo Ekonomiczne.

14. Kamiński, J. (2010). Dlaczego marketingowi potrzebne sa badania historyczne. Marketing $i$ Rynek, 4, 2-8.

15. Kamiński, J. (2012). O „Niektórych problemach dystrybucji rynkowej" A. W. Shawa w setna rocznice pierwszego naukowego opracowania na temat marketingu, Marketing i Rynek, 2, 2-8.

16. Kamiński, J. (2016). Refleksje nad zakresem nauki o marketingu jako dyscypliny naukowej, Marketing $i$ Rynek, 7, 6-16.

17. Kędzior, Z. \& Karcz, K. (2001). Badania marketingowe $w$ praktyce. Warszawa: Polskie Wydawnictwo Ekonomiczne.

18. Koźmiński, A.K. (2009). Ekonomia a inne nauki spoteczne (pp83-91). In B. Fedor \& Z. Hockuba (eds.) Nauki ekonomiczne wobec wyzwań wspótczesności. Warszawa: Polskie Towarzystwo Ekonomiczne.

19. Krysiak, Z. et al. (2010). Podejścia humanistyczne do badania gospodarki (pp. 179-210).

20. In J. Kuciński (ed.) Metodologia nauk ekonomicznych. Dylematy $i$ wyzwania. Warszawa, Difin.

21. Malawski, A. (1999). Metoda aksjomatyczna w ekonomii. Studia nad struktura i ewolucja systemów ekonomicznych. Wrocław-Warszawa-Kraków: Ossolineum.

22. Mauss, M. (2010). Socjologia $i$ antropologia, Warszawa: Wydawnictwo KR.
23. Pilarczyk, B. \& Wanat, T. (2009). Podstawowe dylematy tożsamości marketingu akademickiego. In R. Niestrój (ed.) Tożsamość $i$ wizerunek marketing (pp.112-119). Warszawa: Polskie Wydawnictwo Ekonomiczne.

24. Rószkiewicz, M. et al. (2013). Projektowanie badań społeczno-ekonomicznych. Rekomendacje i praktyki badawcze. Warszawa: Wydawnictwo Naukowe $P W N$.

25. Sagan, A. (2004). Badania marketingowe. Podstawowe kierunki. Kraków: Wydawnictwo Akademii Ekonomicznej w Krakowie.

26. Sagan, A. (2005). Teoretyczne podstawy marketingu 50 lat poszukiwań. Marketing i Rynek, 7, 2-8.

27. Sagan, A. (2013). Zmienne ukryte $w$ badaniach marketingowych. Kraków: Wydawnictwo Uniwersytetu Ekonomicznego w Krakowie.

28. Shaw, E.H., \& Tamilia, R.D. (2001). Robert Bartels and the History of Marketing Thought, Journal of Macromarketing, 2001, 21(2), 156-163.

29. Silverma, D. (2007). Interpretacja danych jakościowych. Warszawa: Wydawnictwo Naukowe $P W N$.

30. Shankar, A. (2009). Reframing critical marketing. Journal of Marketing Management, 25 (7-8), pp. 681-696.

31. Somekh, B. \& Lewin, C. (Eds.). (2011). Theory and Methods in Social Research. Los Angeles: Sage Publications.

32. Surma J. et al. (2010). Podejście naturalistyczne w naukach ekonomicznych. In J. Kuciński (ed.) Metodologia nauk ekonomicznych. Dylematy $i$ wyzwania. Warszawa, Difin.

33. Sztumski, J. (2010). Wstęp do metod i technik badań społecznych, Katowice: Wydawnictwo Naukowe „Śląsk”.

34. Szumilak, J. (2005). W sprawie naukowego statusu marketing. Marketing i Rynek, 8, 2-7.

35. Turner, J.H. (2005). Struktura teorii socjologicznej, Warszawa: Wydawnictwo Naukowe PWN.

36. Wojciechowska, R. (2011). Proces badawczy w naukach ekonomicznych. Warszawa: Oficyna Wydawnicza Szkoła Gtówna Handlowa.

37. Wojtyna, A. (2009). Współczesna ekonomia kontynuacja czy poszukiwanie nowego paradygmatu? (pp. 25-49). In B. Fedor \& Z. Hockuba (eds.) Nauki ekonomiczne wobec wyzwań współczesności. Warszawa: Polskie Towarzystwo Ekonomiczne.

38. Żabiński, L. (2004). Marketing a zarzadzanie. O niektórych relacjach dyscyplinarnych. Prace naukowe AE. W Katowicach, 55-70. 